\title{
Cryopreserved fragments of testicular seminiferous tubules of rats as a source of spermatogonial stem cells
}

\author{
Volkova N., Yukhta M., Sokil L., Chernyschenko L., Stepaniuk L., Goltsev A. \\ Institute for Problems of Cryobiology and Cryomedicine, National Academy of Sciences of Ukraine, Kharkiv, Ukraine \\ Corresponding author’s e-mail: volkovana781@gmail.com
}

\section{ABSTRACT}

The use of modern technologies of cryopreservation of testicular tissue samples in prepubertal patients is one of the ways to maintain their fertility in the future.

The PURPOSE of the study was to investigate the proliferative potential, morphological characteristics and expression of specific markers of cell culture obtained from cryopreserved and vitrified fragments of seminiferous tubules (FSTS) of rats' testis.

MATERIALS AND METHODS. The isolation of cells from native, cryopreserved and vitrified FSTs of immature rats was performed by incubation in a solution of collagenase type IV $(1 \mathrm{mg} / \mathrm{mL})+$ DNase $(500 \mu \mathrm{g} / \mathrm{mL})$. Cell viability was determined by Trypan blue staining. Monoclonal antibodies CD9-FITC, CD24-PE, CD45-FITC, CD90-FITC were used for immunophenotype analysis. Morphological characteristics, proliferative activity (MTT assay), relative number of cells positive for MAGE-B1 and vimentin were assessed in the obtained cultures.

RESULTS. The analysis of phenotypic characteristics showed that cells from native, cryopreserved and vitrified FSTs were characterized by high expression level of $\operatorname{CD9}(\geq 40 \%), \operatorname{CD24}(\geq 70 \%), \operatorname{CD} 90(\geq 70 \%)$ and low expression of the $C D 45(\leq 1 \%)$. In cell culture in vitro, the studied cells from cryopreserved and vitrified rat's FSTs had the ability to adhere and proliferate while maintaining a cells population positive for MAGE-B1 and vimentin.

CONCLUSIONS. The results can be the basis for the development of effective protocols for the cultivation and cryopreservation of testicular spermatogonial stem cells in order to restore fertility in men.

KEY WORDS: testicular tissue; spermatogonial stem cells; cryopreservation

Today, the problem of infertility is an important part of modern medicine. However, this is not only a medical, but also a social problem. A lot of laboratories around the world are conducting large-scale research aimed at studying the causes of human reproductive dysfunction and the development of methods that restore fertility [1]. The activity of spermatogonial stem cells (SSCs) is the basis of spermatogenesis. These cells are sperm progenitors that can renew themselves throughout life, thus supporting the continuous production of sperm during spermatogenesis. The spermatogenesis is the main function of the convoluted tubules and is possible only with close contact of somatic and spermatogonial cells. Isolation, cultivation, cryopreservation, determination of morphological and functional characteristics of spermatogonial cells before transplantation to preserve or restore fertility is an important area of the development of modern biotechnology [2,3].

Various approaches and experimental models are used to recovery male reproductive cells. In vitro studies, such as the cultivation of spermatogonial cells, provide an opportunity for manipulation with the paracrine environment, and also help to study the individual influence of each growth factor on the processes of spermatogenesis $[4,5]$. There is a small amount of studies on the proliferative potential of testicular tissue under culture in vitro. Thus, in the study of Yokonishi T. et al., a method of culturing immature mouse testicular tissue on agarose gel with the followed obtaining spermatozoa is presented [6]. Gohbara A. et al. report the production of round haploid spermatids by culturing testicular tissues [2]. In the study by Mohaqiq M. et al., SSCs were isolated in vitro from cryopreserved human testicular samples and transplanted to adult mice with an experimental model of azoospermia followed by culturing the host's testicular tissue. However, the progress of human SSC spermatogenesis in mouse testes has not been detected [7].

Now, there are two approaches to the cultivation of testicular tissue: sample can be enzymatically digested into a single cell suspension, or applied in the form of fragments. After culturing, in the case of using a cell suspension, its autotransplantation is possible by injection into the testis $[8,9]$. In the case of seminiferous tubules culture, the tissue transplantation is possible to initiate spermatogenesis [10]. 


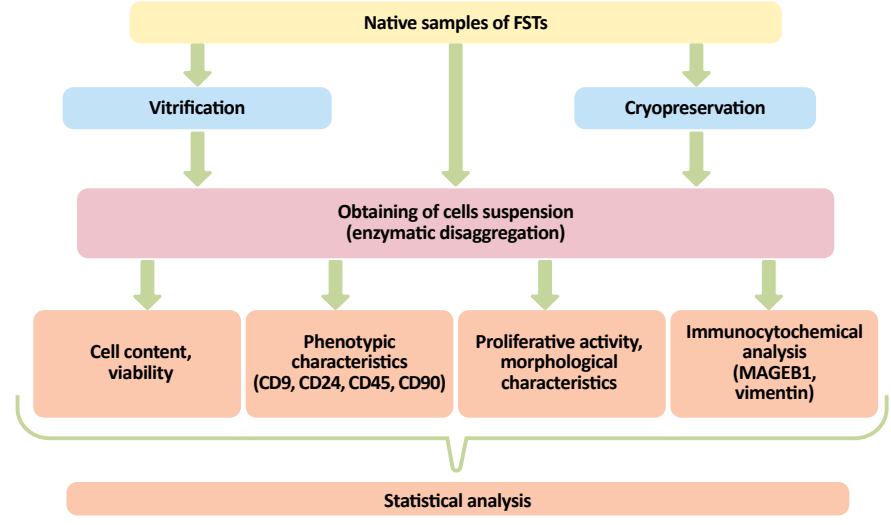

Fig. 1. The scheme of the experiment.

Obtained in this way spermatozoa can be used for fertilization by intracytoplasmic sperm injection [10]. In addition, the literary data is actively considering the possibility of the induction of spermatogenesis in vitro, in particular using thawed spermatogonial tissue, but this technology is still under active development.

The PURPOSE of the study was to investigate the proliferative potential, morphological characteristics and expression of specific markers of cell culture obtained from cryopreserved and vitrified fragments of seminiferous tubules (FSTs) of rats' testis.

\section{MATERIALS AND METHODS}

All animal experiments were performed according to the international principles of bioethics, laws of Ukraine, materials of the IV European Convention for the Protection of Vertebrate Animals Used for Experimental and Other Scientific Purposes, and the protocol of the Institute's Bioethics Committee (№ 2014-02). The rats were kept in plastic cages (five animals in each one) at a controlled temperature $\left(18-22^{\circ} \mathrm{C}\right)$, humidity $(30-70 \%)$ and lighting (light interval from $8^{00}$ to $20^{00}$ ) with free access to water and food according to the standard diet.

FSTs were obtained mechanically from both testes of immature outbred rats aged 7-8 weeks $(n=30)$ after $\mathrm{CO}_{2}$ euthanasia. Testicular tissue samples weighing $75 \pm 3 \mathrm{mg}$ were used for cryopreservation by slow cooling rates [11, 12], or samples weighing $25 \pm 3 \mathrm{mg}$ were used for vitrification $[11,13]$. Cryopreservation using slow cooling rates was performed under the protection of fibrin gel and $6 \%$ glycerol. Freezing was carried out in nitrogen vapor to $-70^{\circ} \mathrm{C}$ for $40 \mathrm{~min}$, followed by transfer to liquid nitrogen $\left(-196^{\circ} \mathrm{C}\right)$. Thawing was performed in a water bath at $40^{\circ} \mathrm{C}$ with pre-incubation in liquid nitrogen vapor. Combinations of cryoprotectants were used for vitrification of FSTs: medium 1 (fibrin gel $+5 \%$ DMSO + $6 \%$ glycerol $+0.1 \mathrm{M}$ sucrose) and medium 2 (fibrin gel $+15 \%$ DMSO $+18 \%$ glycerol $+0.5 \mathrm{M}$ sucrose). Sequential exposure of FSTs to media 1 and 2 was performed for $5 \mathrm{~min}$ in each at a temperature of $4{ }^{\circ} \mathrm{C}$, followed by rapid transfer in liquid nitrogen. Thawing was performed in $1 \mathrm{M}$ sucrose solution at a temperature of $50^{\circ} \mathrm{C}$ with sequential transfer of samples into sucrose solutions of decreasing concentration $(0.5,0.25$ and $0 \mathrm{M}$ ) at a temperature of $20^{\circ} \mathrm{C}$. FSTs samples of native tissue were used as a control. The scheme of the experiment is shown in Fig. 1.

Isolation of cells from the fragments of seminiferous tubules was performed by enzymatic digestion in a solution of collagenase type IV $1 \mathrm{mg} / \mathrm{mL}$ (Gibco, UK) $+500 \mu \mathrm{g} / \mathrm{mL}$ DNase (Sigma, USA) at $37^{\circ} \mathrm{C}$ for $15 \mathrm{~min}$ followed by centrifugation at $250 \mathrm{xg}$ for 5 min and filtration through a nylon filter with a pore diameter of $100 \mu \mathrm{m}$. The number of cells in the obtained samples was counted using a Goryaev chamber and calculated per $1 \mathrm{mg}$ mass of fragment. Cell viability was determined by Trypan blue staining.

The cell suspension after enzymatic digestion was resuspended in complete nutrient medium containing aMEM (PAA, Austria), $10 \%$ fetal bovine serum (HyClone, USA), $150 \mu \mathrm{g} / \mathrm{mL}$ gentamicin (Farmak, Ukraine) and $1 \mu \mathrm{g} / \mathrm{mL}$ amphotericin B (PAA, Austria). The cell culture density was $1 \cdot 10^{3} \mathrm{cells} / \mathrm{cm}^{2}$ of a culture flask with an area of $25 \mathrm{~cm}^{2}$ (PAA, Austria). The nutrient medium was changed every 3 days. The standard culture conditions at $37^{\circ} \mathrm{C}$ in an atmosphere of $5 \% \mathrm{CO}_{2}$ using an incubator (Biosan, Lithuania) were used in the study. Upon reaching a monolayer, cell cultures were subcultured using a $0.25 \%$ solution of trypsin (PAA, Austria) and versene (PanEco, Russia) in a ratio of 1:1.

On the $5^{\text {th }}$ and $10^{\text {th }}$ days, cell cultures were fixed with $4 \%$ paraformaldehyde solution, followed by azure-II and eosin staining by RomanovskyGimza.

On the $1^{\text {st }}, 3^{\text {rd }}, 7^{\text {th }}$, and $10^{\text {th }}$ days of cultivation, the proliferative activity of cells in the studied cultures was determined using the MTT assay. For this, $0.5 \mathrm{ml}$ of MTT solution (Sigma, USA) at a concentration of $5 \mathrm{mg} / \mathrm{mL}$ was added to the test samples and incubated for 3 hours at $37^{\circ} \mathrm{C}$. Then the medium was completely removed and dimethyl sulfoxide (PanEco, Russia) $1 \mathrm{~mL}$ per sample was added to dissolve the formazan, followed by centrifugation for $10 \mathrm{~min}$ at $1000 \mathrm{xg}$. The optical density of a solution of formazan in the supernatant was measured using a biochemical analyzer CHEM 7 (ERBA, Czech Republic) at a wavelength of $540 \mathrm{~nm}$. Cell-free medium was used as a control sample.

For phenotypic analysis, cells were stained with anti-CD9 primary monoclonal antibody (cat. № 551808) followed by FITC labeled secondary goat anti-mouse antibody (cat. № 554001), anti-CD24-PE (cat. № 562104), anti-CD45-FITC (cat. № 561867), anti-CD90-FITC (cat. № 561973 ) according to the manufacturer's instructions (BD Biosciences, USA). The results were analyzed on a flow cytometer FACS Calibur (Becton Dickinson, USA) using the Win MDI v.2.8 software.

Immunocytochemical staining of cultured cells was performed using polyclonal antibodies to MAGE-B1 (cat. № PA5-51532, Invitrogen, USA) at a dilution of 1:500 (specificity to rat ortholog is $53 \%$ ) [14] and vimentin at a dilution of 1:200 (cat. № PA5-27231, Invitrogen, USA). Staining was performed according to the protocol recommended for the peroxidase detection system Ultra Vision Quantro HRP DAB (Thermo Fisher, USA). Using Axiovision Real 4.7 software (Carl Zeiss, Germany), cells stained for MAGE-B1 or vimentin were counted and their percentage was determined as the ratio of the number of stained cells to the total number of cells (per $1 \mathrm{~mm}^{2}$ ). For negative control of MAGE-B1 and vimentin, cell staining was performed according to the same protocol with the mouse $\lg \mathrm{G}$ isotype.

Table 1. The number and viability of cells derived from FSTs of rats

\begin{tabular}{|c|c|c|}
\hline SAMMLE & $\begin{array}{c}\text { NUMBER OF CELLS, } \\
\text { x104 PER 1 mg OF TISSUE }\end{array}$ & VIABILITY, \% \\
\hline Native FSTs & $1.92 \pm 0.12$ & $80.5 \pm 3.9$ \\
\hline Cryopreserved FSTS & $1.88 \pm 0.15$ & $61.7 \pm 5.8^{*}$ \\
\hline Vitrified FSTS & $1.81 \pm 0.13$ & $48.5 \pm 6.2^{*}$ \\
\hline
\end{tabular}

Note: * $-p<0.05$ compared to the group of native samples $(n=15)$

Table 2. The phenotype of cells from the fragments of seminiferous tubules of immature rat's testis.

\begin{tabular}{|c|c|c|c|}
\hline & \multicolumn{3}{|c|}{ EXPRESSION BY FLOW CYTOMETRY, \% } \\
\hline & $\begin{array}{l}\text { NATIVE FSTs } \\
(n=15)\end{array}$ & $\begin{array}{l}\text { CRYOPRESERVED FSTS } \\
\qquad(n=15)\end{array}$ & $\begin{array}{l}\text { VITRIFIED FSTs } \\
\qquad(n=15)\end{array}$ \\
\hline CD9 & $45.4 \pm 0.5$ & $43.1 \pm 0.6$ & $44.1 \pm 0.3$ \\
\hline CD24 & $71.4 \pm 0.7$ & $70.1 \pm 0.3$ & $72.3 \pm 0.4$ \\
\hline CD45 & $1.1 \pm 0.2$ & $1.2 \pm 0.5$ & $0.9 \pm 0.2$ \\
\hline CD90 & $78.5 \pm 0.5$ & $71.6 \pm 0.3$ & $70.6 \pm 0.3$ \\
\hline
\end{tabular}


The normality of the distribution was determined by the skewness and the kurtosis. In the normal distribution of variables, the significance of differences between groups was estimated using one-way analysis of variance (ANOVA) with Bonferroni correction. The data are presented as means and standard deviations ( $\mathrm{M} \pm \sigma$ ). The critical value of the significance level was assumed to be $p=0.05$. Data analysis was performed using Microsoft Excel (Microsoft, USA) and Statistica 8 (StatSoft Inc., USA) software.

\section{RESULTS AND DISCUSSION}

The first stage of the experiment was to study the number and viability of cells from native, cryopreserved and vitrified rat FSTs. The obtained data by groups are presented in table 1. Enzymatic digestion of native seminiferous tubules of rats after their low-temperature storage allows to obtain $1.81-1.92 \cdot 10^{4}$ cells from a sample weighing $1 \mathrm{mg}$.

It should be noted that despite the same number of cells from studied samples of FSTs, their viability differed. Thus, in cells from cryopreserved fragments, it was 1.3 times higher than in vitrified FSTs. However, the integrity of the cell membrane after both types of low-temperature storage was significantly lower than in native FSTs.

Based on the studies of several authors, the surface phenotype of SSCs is characterized by the expression of a6-Integrin (CD49f), $\beta 1$-Integrin (CD29), Thy-1 (CD90), CD9, CD24, GFRa1, CDH1, in the absence of expression of av-Integrin (CD51), c-kit (CD117), major histocompatibility complex class I (MHC-I), CD45 [15-17]. The results obtained in our study showed that the studied cells, regardless of the source (native, cryopreserved or vitrified FSTs) showed the same phenotype with the high level of expression of markers CD9 ( $\geq 40 \%)$, CD24 ( $\geq 70 \%)$, $\operatorname{CD} 90(\geq 70 \%)$ and low for CD45 $(\leq 1 \%)$.

CD9 is known to be a protein of the tetraspanin family that is commonly expressed on rat SSCs, is involved in cell adhesion, and promotes the functional regulation of integrins. Significant expression of CD9 was found in the epithelial cells of the epididymis, prostate, and spermatozoa [18]. The marker CD24 is expressed in many cell types, and it is usually more on stem and metabolically active cells and less on cells that have

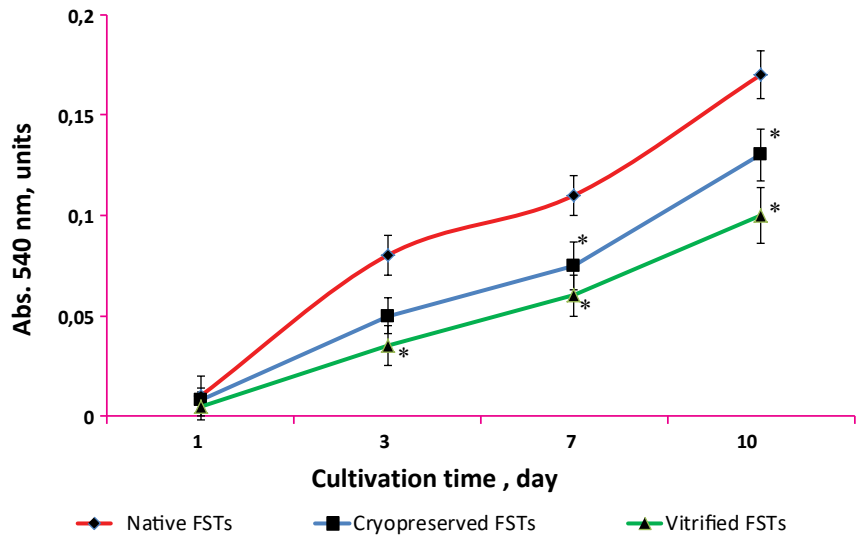

Fig. 2. The proliferative activity of cells obtained from native, cryopreserved and vitrified FSTs of immature rats in the passage 0 . Note: ${ }^{*}-p<0.05$ compared to native FSTs samples $(n=15)$

reached the terminal stage of differentiation [16]. The cell surface glycoprotein CD90 (thymus cell antigen 1, Thy 1 ) is recognized as a surface marker of SSCs, which in modern studies has been successfully used to obtain an enriched population of these cells using MACS [18]. Leydig progenitor cells associated with testicular tubules are also known to be CD90-positive, but they are negative for other SSCs markers and are characterized by high expression levels of all potential markers of Leydig cells: Nestin, CD51, COUP transcription factor 2 (COUP-TF2), Arx, platelet derived growth factor receptor alpha (PDGFRa) and transcription factor 21 (TCF21) [20].

The next step was to determine the ability to proliferate cells obtained from samples of rat FSTs (Fig. 2). The growth dynamics of the studied cultures were similar, but the growth of cells was greater in the samples from native FSTs throughout the observation period. Thus, on the $3^{\text {rd }}$ day of observation in the cultures from cryopreserved and vitrified samples, the studied parameter was probably lower by 1.6 and 2.2 times, on the $7^{\text {th }}$ day - by 1.4 and 1.8 times, on the $10^{\text {th }}$ day - by 1.3 and 1.7 times, respectively, compared to native samples.
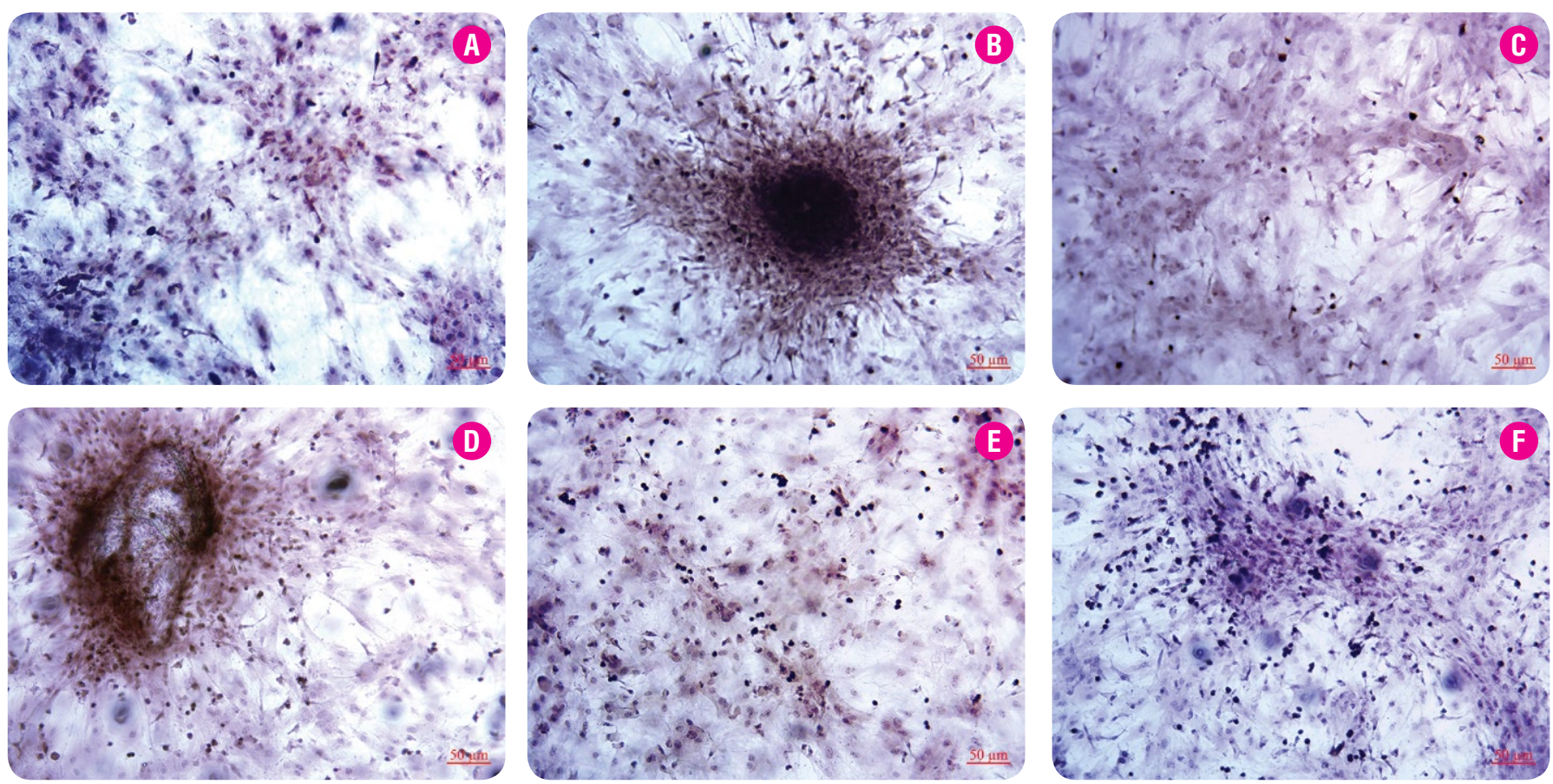

Fig. 3. Micrographs of cell cultures obtained from native $(\mathbf{A}, \mathbf{B})$, cryopreserved $(\mathbf{C}, \mathbf{D})$, and vitrified FSTs $(\mathbf{E}, \mathbf{F})$ of rats on the $5^{\text {th }}$ day $(\mathbf{A}, \mathbf{C}, \mathbf{E})$ and the $10^{\text {th }}$ day (B, D, F) of cultivation. Light microscopy, azure-eosin staining; scale $-50 \mu \mathrm{m}$. 

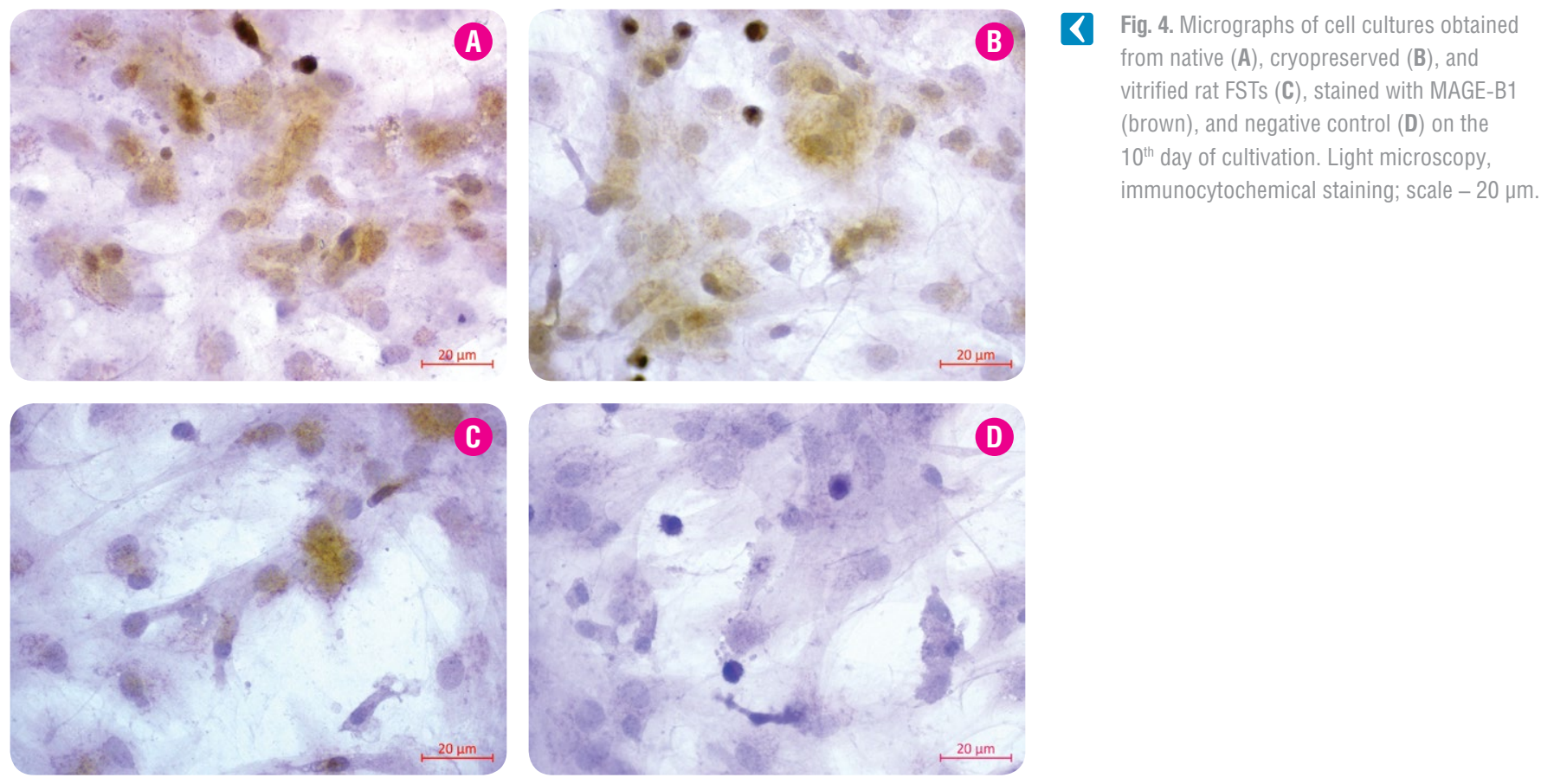

It should be noted that in the $2^{\text {nd }}$ passage the studied cell cultures from cryopreserved FSTs had a higher ability to proliferate than during passage 0 . This phenomenon is probably related, on the one hand, to the inhibition of proliferative activity after cryopreservation, and, on the other hand, to the adaptation of cells to culture conditions [21].

The results of the study of morphological characteristics of cells obtained from native, cryopreserved and vitrified FSTs of immature rats, on the $5^{\text {th }}$ and $10^{\text {th }}$ day of cultivation are shown in Fig. 3.

In cultures, regardless of the source, cells were divided into three types by size and shape: spindle-shaped, polygonal and round. Round cells were placed on spindle-shaped and polygonal cells in the second layer and colonies were formed when the culture term was increased to 10 days. According to the authors [22, 23], these cells are a pool of spermatogonial undifferentiated cells. It should be noted that after both types of cryopreservation, the number of colonies was less than in the culture of native fragments. According to the size and cell density, the colonies were divided into two types: dense $(200-300 \mu \mathrm{m})$ and diffuse $(50-70 \mu \mathrm{m})$ ones. The largest number of dense colonies was observed in cell cultures derived from native FSTs. Small colonies were typical for cell cultures from cryopreserved and vitrified FSTs.

It is known that MAGE-B1 is expressed in haploid spermatids, which are located on the inner layer of immature convoluted tubules. They are small cells with a light nucleus, which lie in several layers. Early spermatids have a round shape with a spherical nucleus and are located in the middle layers of the spermatogenic epithelium. Late spermatids lie in a layer adjacent to the lumen of the tubule and have an elongated shape. Spermatids, as a rule, are grouped in the thickness of spermatocytes and differ in a smaller size [24]. The presence and distribution of spermatogonial cells positive for MAGE-B1 were studied for rat FSTs cell culture on the $10^{\text {th }}$ day using polyclonal antibodies. Immunoreactivity to MAGE-B1 in the cell cultures was observed by the concentration of brown color around the nuclei and in the cytoplasm of cells. The obtained results of immunocytochemical staining for MAGE-B1 cultured cells from native, cryopreserved and vitrified rat FSTs are shown in Fig. 4.

Light microscopy showed the presence of $69.6 \pm 2.7 \%$ cells stained for MAGE-B1 in the cultures from native FSTs. In cell cultures derived from cryopreserved and vitrified samples, the determination of the relative number of cells stained for MAGE-B1 showed a decrease by 1.3 $(53.5 \pm 3.5 \%, p<0.05)$ and $1.5(46.7 \pm 2.9 \%, p<0.05)$ times, respectively, relatively to the cell cultures from native FSTs.
The cytoskeleton of terminally differentiated mammalian Sertoli cells is one of the most complex among described ones. Actin filaments, intermediate filaments and microtubules have different distribution niches that change during the cyclic process of spermatogenesis. Each of the three main elements of the cytoskeleton is either concentrated in the intercellular gaps, or partially associated with them. Actin filaments are concentrated in unique structures involved in intercellular adhesion and in tubulobulbar complexes, which are thought to be involved in the internalization of compounds during sperm release and sperm cell movement through basal connections between adjacent Sertoli cells. Unlike most other epithelia, where the intermediate filaments belong to the keratin type, the intermediate filaments in mature Sertoli cells belong to the vimentin type [25-27]. The results of immunocytochemical staining for vimentin of cultured cells obtained from native, cryopreserved and vitrified rat FSTs are shown in Fig. $\mathbf{5}$.

The presence and distribution of filaments such as vimentin were examined on the $10^{\text {th }}$ day of cultivation using monoclonal antibodies. At the structural level, immunoreactivity to vimentin was observed by the concentration of brown color around the nuclei and in the cytoplasm of cells. In cultures from native FSTs, the relative number of cells stained for vimentin was $21.7 \pm 1.8 \%$. Determination of this parameter in cultures obtained from cryopreserved and vitrified FSTs showed the presence of $15.5 \pm 2.1 \%$ and $11.4 \pm 1.7 \%$ stained cells, which is 1.4 and 1.9 times lower $(p<0.05)$, respectively, compared to cells from native FSTs.

In the study of O'Donnell L. et al. when performing 3D-reconstructions, Sertoli cells showed certain configurations of variable filaments at different stages of spermatogenesis [26]. In particular, according to the results of morphological and immunohistochemical analysis, filaments of vimentin in sustenocytes from patients with obstructive azoospermia were characterized by pathological changes (disruption of spermatogenesis, Sertoli cell only syndrome). Thus, filaments play an important role in the adaptation of these cells to various changes that occur in neighboring cells during spermatogenesis, as well as in pathological conditions [26-28].

Thus, in our study, it was shown that cryopreserved using slow cooling rates and by vitrification FSTs retained the population of $\mathrm{CD} 9^{+}, \mathrm{CD} 24^{+}$, CD90+ and CD45- cells and can be used as a source of SSCs. However, it should be noted that in the thawed tissue intracellular processes slow down and viability and proliferation slightly decrease, which probably leads to a decrease in the number of cells expressing MAGE-B1 and vi- 

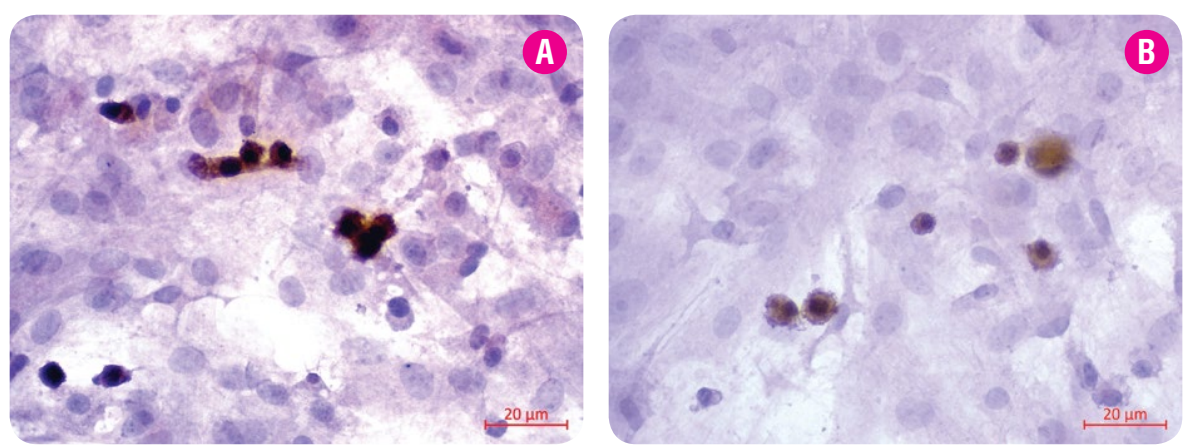

\ig. 5. Micrographs of cell cultures obtained from native (A), cryopreserved (B), and vitrified rat FSTs (C), stained for vimentin (brown) and negative control (D) on the $10^{\text {th }}$ day of cultivation. Light microscopy, immunocytochemical staining; scale $-20 \mu \mathrm{m}$.
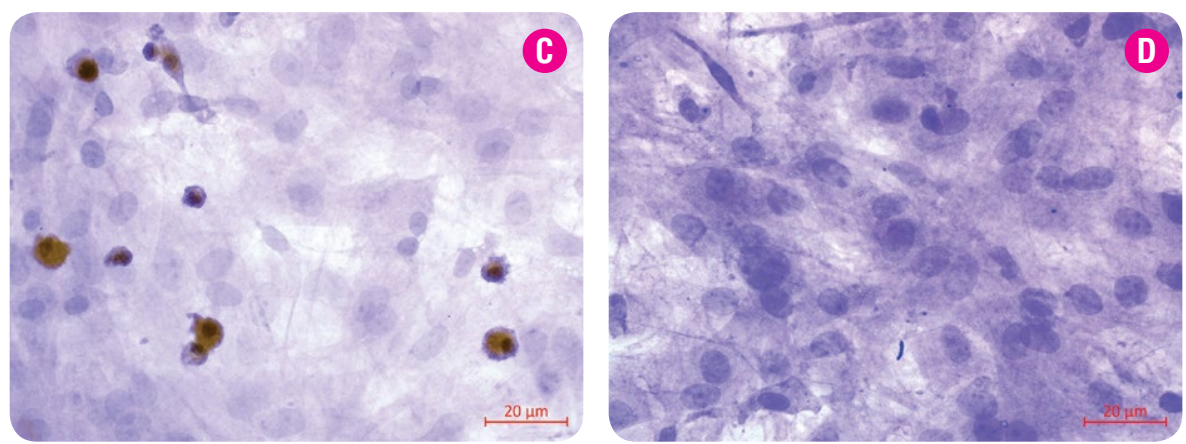

mentin on the $10^{\text {th }}$ day of cultivation compared to the native samples. The ability to restore fertility in men has a great potential in basic and applied

conditions has a twofold effect: on the one hand, there is an increase in the proliferative activity of SSCs due to the addition of certain factors, on the other hand, violations of their functionality due to the same supplements are possible [32]. The use of a number of techniques that improve the conditions of cultivation, allowed providing a long-term increase in the hope for the preservation of fertility in such cases as cytotoxic therapy in prepubertal cancer patients [30].

Worth noting, that the future clinical use of spermatogonial cells requires the development of cell culture techniques without xenogeneic and feeder culture systems. The use of somatic cells present in testicular biopsies helps to maintain SSCs and may allow avoiding the use of exogenous cells as a feeder layer. On the other hand, cultivation in serumfree media without growth factors may affect the function of the SSCs and lead to a decrease in their potential [31]. That is, the modulation of cultural pool of SSCs, which maintained an undifferentiated state for 12 passages without the loss of function and ability to restore normal spermatogenesis after transplantation [33]. In addition, a number of studies have shown that SSCs are able to differentiate into different cell types in vitro, such as cardiomyocytes and neural cells [34, 35]. Based on these assumptions, SSCs may be one of the most promising candidates for clinical applications in the field of reproductive medicine and cell therapy [36]

\section{CONCLUSION}

1. Cells derived from native, cryopreserved and vitrified fragments of rat's seminiferous tubules have the same level of CD9, CD24, CD90 and CD45 expression.

2. Under culture conditions, the ability to proliferate and maintain a population of MAGE-B1 and vimentin-positive cells derived from cryopreserved and vitrified FSTs has been demonstrated.

3. Cryopreserved using slow cooling rates and by vitrification FSTs can be used as a source of spermatogonial stem cells to restore fertility in men.

The study was carried out within the program of the National Academy of Sciences of Ukraine «Support for the development of priority areas of research» (code 6541230), agreement № 2.2.6.130.

\section{REFERENCES}

1. Song H, Wilkinson M. In vitro spermatogenesis a long journey to get tails. Spermatogenesis. 2012; 2(4):1-7. DOI: 10.4161/spmg.22069.

2. Gohbara A, Katagiri K, Sato T, et al. In vitro murine spermatogenesis in an organ culture system. Biol Reprod. 2010; 83:261-267. DOl: 10.1095/biolreprod.110.083899.

3. Uchida A, Dobrinski I. Germ cell transplantation and neospermatogenesis. Cham: Springer international publishing AG. 2018; 2018:361-375. DOI: 10.1007/978-3319-42396-8_20.

4. Goossens E, Tournaye H. Adult stem cells in the human testis. Semin Reprod Med. 2013; 31(1):39-48. DOI: 10.1055/s-0032-1331796.

5. Smith JF, Yango P, Altman E, et al. Testicular niche required for human spermatogonial stem cell expansion. Stem Cells Transl Med. 2014; 3(9):1043-1054. D0I: 10.5966/sctm.2014-0045. 
6. Yokonishi T, Sato T, Katagiri K, et al. In vitro spermatogenesis using anorgan culture technique. Methods Mol Biol. 2013; 927:479-488. D0I: 10.1007/978-1-62703038-0_41.

7. Mohaqiq M, Movahedin M, Mazaheri Z, et al. In vitro transplantation of spermatogonial stem cells isolated from human frozen-thawed testis tissue can induce spermatogenesis under 3-dimensional tissue culture conditions. Biol Res. 2019; 52(1):16. DOI: 10.1186/s40659-019-0223-x.

8. Sato $T$, Katagiri $K$, Kubota $Y$, et al. In vitro sperm production from mouse spermatogonial stem cell lines using an organ culture method. Nat Protoc. 2013; 8(11):2098-2104. DOI: 10.1038/nprot.2013.138.

9. Baert $Y$, Braye A, Struijk RB, et al. Cryopreservation of testicular tissue before long-term testicular cell culture does not alter in vitro cell. Fertil Steril. 2015; 104(5):1244-1252. DOI: 10.1016/j.fertnstert.2015.07.1134.

10. Ginsburg ES, Yanushpolsky EH, Jackson KV. In vitro fertilization for cancer patients and survivors. Fertil Steril. 2001; 75(4):705-710. D0I: 10.1016/s00150282(00)01802-1.

11. Volkova N, Yukhta $M$, Goltsev A. Biopolymer gels as a basis of cryoprotective medium for testicular tissue of rats. Cell Tissue Bank. 2018 ; $19(4): 819-826$. DOI:10.1007/s10561-018-9740-z

12. Volkova NO, Yukhta MS, Chernyshenko LG, et al. Cryopreservation of rat seminiferous tubules using biopolymers and slow non-controlled rate cooling. Probl Cryobiol Cryomedicine. 2018; 28(4):278-292. D0I: 10.15407/cryo28.04.278.

13. Volkova NO, Yukhta MS, Goltsev AM. Vitrification of rat testicular tissue using biopolymers. Biopolym Cell. 2020; 36(2):122-132. D0I: $10.7124 /$ bc.000A26.

14. Zhao Q, Caballero OL, Simpson AJG, Strausberg RL Differential evolution of MAGE genes based on expression pattern and selection pressure. PLoS ONE. 2012; 7(10):e48240. DOl.org/10.1371/journal.pone.0048240

15. Shinohara T, Avarbock MR, Brinster RL. 31 -and a6-integrin are surface markers on mouse spermatogonial stem cells. PNAS. 1999; 96(10):5504-5509. D0I: 10.1073/pnas.96.10.5504.

16. Kubota H, Avarbock MR, Brinster RL. Spermatogonial stem cells share some, but not all, phenotypic and functional characteristics with other stem cells. PNAS 2003; 100(11):6487-6492. DOI: 10.1073/pnas.0631767100.

17. Phillips BT, Gassei K, Orwig KE. Spermatogonial stem cell regulation and spermatogenesis. Philosophical Transactions of the Royal Society B: Biol Sci. 2010; 365(1546):1663-1678. DOl: 10.1098/rstb.2010.0026.

18. Kanatsu-Shinohara M, Toyokuni S, Shinohara T. CD9 is a surface marker on mouse and rat male germline stem cells. Biol Reprod. 2004; 70(1):70-75. D0l: 10.1095/biolreprod.103.020867.

19. Ibtisham F, Honaramooz A. Spermatogonial Stem Cells for In Vitro Spermatogenesis and In Vivo Restoration of Fertility. Cells. 2020; 9(3):745. D0I: 10.3390/ cells9030745.

20. Guan X, Chen $P$, Zhao X, et al. Characterization of stem cells associated with seminiferous tubule of adult rat testis for their potential to form Leydig cells. Stem cell Res. 2019; 41:101593. DOI: 10.1016/j.scr.2019.101593.

21. Haack-Sorensen M, Bindslev L, Mortensen S, et al. The influence of freezing and storage on the characteristics and functions of human mesenchymal stromal cells isolated for clinical use. Cytotherapy. 2007; 9(4):328-337. DOl: 10.1080/14653240701322235.

22. Maleki M, Ghanbarvand F, Behvarz, MR, et al. Comparison of mesenchymal stem cell markers in multiple human adult stem cells. Int J Stem Cell. $2014 ; \mathbf{7 ( 2 ) : ~} 118$. DOI: 10.15283/ijsc.2014.7.2.118.

23. Aponte PM, Soda T, Van De Kant HJG, de Rooij DG. Basic features of bovine spermatogonial culture and effects of glial cell line-derived neurotrophic factor Theriogenology. 2006; 65(9): 1828-1847. DOI:10.1016/j.theriogenology.2005.10.020

24. Quintana M, Fon Tacer K, Hao YH, et al. Examining the temporal expression and regulation of type I MAGE proteins in spermatogenesis. FASEB J. 2014; 28(S1):930.

25. Vogl AW, Vaid KS, Guttman JA. The Sertoli cell cytoskeleton. Adv Exp Med Biol. 2008; 636:186-211. D0I: 10.1007/978-0-387-09597-411.

26. O'Donnell L, O'Bryan MK. Microtubules and spermatogenesis. Semin Cell Dev Biol. 2014; 30:45-54. D0I: 10.1016/j.semcdb.2014.01.003.

27. Wu S, Yan M, Ge R, et al. Crosstalk between sertoli and germ cells in male fertility. Trends Mol Med. 2020; 26(2):215-231. D0I: 10.1016/j.molmed.2019.09.006.

28. Sharma S, Wistuba J, Pock T, et al. Spermatogonial stem cells: updates from specification to clinical relevance. Hum Reprod Update. 2019; 25(3):275-29. D0I: 10.1093/humupd/dmz006.

29. Struijk RB, Mulder CL, Veen van der F, et al. Restoring fertility in sterile childhood cancer sur-vivors by autotransplanting spermatogonial stem cells: are we there yet? BioMed Res Int. 2013; 2013:903142. DOI: 10.1155/2013/903142.

30. Kanatsu-Shinohara M, Takashima S, Ishii K, et al. Dynamic changes in EPCAM expression during spermatogonial stem cell differentiation in the mouse testis. PloS One. 2011; 6(8):e23663. DOl: 10.1371/journal.pone.0023663.

31. Guo $Y$, Hai $Y$, Gong $Y$, et al. Characterization, isolation, and culture of mouse and human spermatogonial stem cells. J Cell Physiol. 2014; 229(4):407-413. D0I: 10.1002/jcp.24471.

32. Hamra FK, Chapman KM, Nguyen DM, et al. Self renewal, expansion, and transfection of rat spermatogonial stem cells in culture. PNAS USA. 2005; 102:1743017435. DOI: 10.1073/pnas.0508780102.

33. Nagano MC. Techniques for culturing spermatogonial stem cells continue to improve. Biol Reprod. 2011; 84(1):5-6. D0I: 10.1095/biolreprod.110.088864.

34. Guan K, Wagner S, Unsöld B, et al. Generation of functional cardiomyocytes from adult mouse spermatogonial stem cells. Circ Res. 2007; 100(11):1615-25. D0I: 10.1161/01.RES.0000269182.22798.d9.

35. Bojnordi MN, Azizi H, Skutella T, et al. Differentiation of Spermatogonia Stem Cells into Functional Mature Neurons Characterized with Differential Gene Expression. Mol Neurobiol. 2017; 54(7):5676-5682. DOI: 10.1007/s12035-016-0097-7.

36. Hwang YS, Suzuki S, Seita Y. Reconstitution of prospermatogonial specification in vitro from human induced pluripotent stem cells. Nat commun. 2020; 11(1):117. DOI: $10.1038 / \mathrm{s} 41467-020-19350-3$

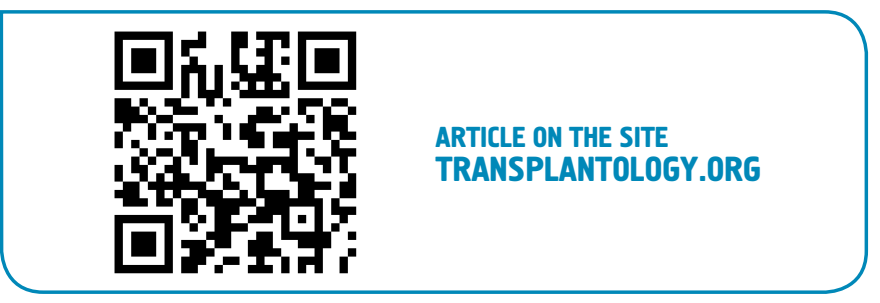

The authors declared no potential conflicts of interest with respect to the research, authorship, and/or publication of this article. 


\section{Кріоконсервовані фрагменти звитих канальців сім’яників щурів як джерело сперматогоніальних стовбурових клітин}

Волкова Н. О., Юхта М. С., Сокіл Л. В., Чернишенко Л. Г., Степанюк Л. В., Гольцев А. М.

Інститут проблем кріобіології і кріомедицини НАН України, м. Харків, Україна

\section{PE3ЮME}

Застосування сучасних технологій кріоконсервування біоптатів тестикулярної тканини у пацієнтів препубертатного віку є одним із способів зберегти у майбутньому їх фертильність.

META РОБОТИ - встановити проліфреративний потенціал, морфологічні характеристики та експресію окремих маркерів клітин із кріоконсервованих та вітрифікованих фрагментів звитих канальців сім'яників (ФЗКС) щурів за умов культивування.

MATEPІАЛИ ТА МЕТОДИ. Виділення клітин з нативних, кріоконсервованих та вітриффікованих ФЗКС статевонезрілих щурів проводили шляхом інкубації у розчині колагенази IV типу (1 мг/мл) + ДНКази (500 мкг/мл). Життєздатність клітин визначали за методом суправітального фрарбування трипановим синім. Для фенотипічного аналізу методом проточної цитометрії використовували моноклональні антитіла проти CD9, CD24, CD45, CD90. В отриманих культурах оцінювали морфологічні характеристики, пролісреративну активність (MTT-тест), відносну кількість клітин, позитивно забарвлених імуноцитохімічно на MAGE-B1 та віментин.

РЕзУЛЬТАТИ. Аналіз фенотипічних характеристик показав, що клітини з нативних, кріоконсервованих та вітрифрікованих ФЗКС

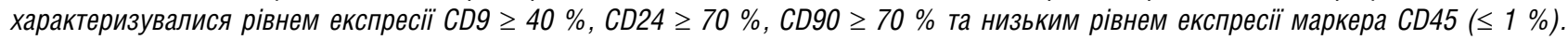
За умов культивування досліджені клітини з кріоконсервованих та вітрифікованих ФЗКС щурів мали здатність до адгезії та пролісерації зі збереженням популяції позитивних на MAGE-B1 та віментин клітин.

висновки. Отримані результати можуть бути основою для розробки ефективних протоколів культивування та кріоконсервування сперматогоніальних стовбурових клітин сім'яників з метою відновлення фертильності у чоловіків.

кЛючовІ СловА: тестикулярна тканина; сперматогоніальні стовбурові клітини; кріоконсервування 